\title{
IMPACT OF GREEN PRACTICES ON BUYING HABITS IN PAKISTAN'S FOOD SECTOR
}

\author{
Rana Adeel Jafar ${ }^{1}$, Aiza Shabbir ${ }^{1}$, Farzana Kousar ${ }^{1}$
}

date of paper receipt:

date of sending to review:

date of review receipt:

04.07.2019.

08.07.2019.

26.07.2019.

Review Article

doi:10.2478/eoik-2019-0012

UDK:

641:339.13]:334.72.021(549.1)

${ }^{1}$ Department of Economics, Superior University-Raiwind Road Lahore, Pakistan

\begin{abstract}
The review intends to research the green advertising practices and its consequences for the client's image inclination in sustenance segment of Pakistan.

Design/methodology/approach- Data is gathered by using 5 point scale through strongly disagree to strongly agree it include 15 items about respondents graphics It contains questions about demographics, green brand image, environment concern, green brand awareness, and green brand preferences. The data was collected from different Universities (G.C University, University of Punjab, University of Engineering and Technology) in Lahore Pakistan. In this study cluster sampling is used.

Findings- This study shows significant results with respect to green brand preference and its critical characteristics of student brand awareness. This study concluded that the importance of green brand elements (green brand image, environment concern, on green brand awareness, H1 $\mathrm{H} 2 \mathrm{H} 4 . \mathrm{H} 4$ are accepted.

Originality - Past writing recommends an Essential association among green showcasing and purchaser mark inclinations yet in Pakistan there is an absence of such examination. So to fill this hole this exploration is led by utilizing quantitative procedures. We circulate poll 60 shoppers and capability of sustenance segment on the premise of accommodation examining to get the outcomes with regards to Pakistan.
\end{abstract}

\section{Keywords:}

Green brand image, Environmental concern, Green brand awareness, Green brand preferences. 


\section{INTRODUCTION:}

Green advertising is one of the most recent showcasing ideas. It has possessed the psyche and creative energy from the late twentieth century. It is a more up to date idea of showcasing to speak with clients by getting a handle on their consideration through making them understand that it is so imperative to protect nature. What's more, that everybody must be a section in doing as such and the piece of a shopper is to utilize green items and bolster and incline toward the brands that are becoming environmentally viable and are doing endeavors to make this world a more secure place for all of us. The relating impacts of Green showcasing are more secure condition, clients concern, and more client fascination. By advancing these organizations pass on their message to clients in an all the more persuading way. Green advertising includes numerous business practices which mean satisfy shopper request additionally decreased the awful impact on the common habitat.

Green advertising additionally considers to an association that puts its battles into supporting, estimating, and dispersing products with eco-concerns. Around the globe there are resorts that are beginning to propel themselves as "ecotourism" workplaces, i.e., workplaces that "rehearse" in experiencing nature or working in a way that limits their environmental impact. In the more amplified term, the journey for viability will ask for fundamental changes to the organization perspective which underpins publicizing and exchange business limits. The establishments of green publicizing can be taken after back to the inundation of normal stress of the 1970s which created the 'natural advancing' thought.

\section{OBJECTIVES OF THE STUDY}

- To identify the effects of Green brand image on consumer brand preference.

- To Measure the relation of environmental concern and green brand preferences.

- To find the effects of Green brand awareness on customer brand preferences.

\section{LITERATURE REVIEW}

Despite appearing in the mid-1980s, it is only now that greenwashing is mostly accepted, and people seem to relate it to the practice of exaggerated and undeserved claims of environmental friendliness to gain higher market shares (Mukherjee and Ghosh, 2014). Greenwashing is described as the practices of companies over claiming the environmental functionality of their green product or brand that cannot be sustained (Parguel et al., 2011).

Apart from that, it hurts brand image creating doubt among consumers about green marketing activities of the company (Polonsky et al., 2010). Companies try hard to enhance brand loyalty for increasing the sale of their green products or brands by improving functionality (Chen, 2013).

Schubert, Kandampully, Solnet, and Kralj (2010), stated that foodservice manufacturing can have a destructive effect on the environment by the giving those products which clean up the surroundings; excessive use of water; non-recyclable commodities and uncreative procedures of reproducing; consumption of harmful chemical substances in our products can have adverse effects on the environment. Brand Preference Newing (2011). Worldwide, $74 \%$ customers declared they are green or desire for green environment friendly foodstuffs. Vermeir \& Verbeke (2004) sustainable manufacturing and utilization is improved at all stages of cultivation and foodstuff will boost the potential influence of sustainability retains on buyer choice for buying" Sustainable products are encouraged by highlighting individual consequence and significance to individual. Various consumers reveal that sustainable foodstuff is healthier as flavor; feature, protection, and originality are measured (Vermeir \& Verbeke, 2004). Customers favor those hotels which approve green practices; for the reason they increase green practices, customers will build up a taste for them as well as they get awareness about those hotels which apply green practices (Manaktola \& Jauhari 2007). 
Consumers are appreciably aware of green commodities; but the performance of the attribute functioning is an elusive task to do with by the application of green marketing (Juwaheer, 2005). The ecological impact of green stratagem is clear to the society due to which government has changed its laws as a result of which the demand of consumer has also changed; as fallout, there's greater stress on the firms (Anonymous, 2014). Cherian \& Jacob (2012) derived that customers lack green awareness and because of this less awareness, firms are still not spotlighting towards expansion of green products. Consumers are enthusiastic to give for commodities that are mutually and economically in command (Kalafatis\& Pollard, 1999).

Environmental concern promotes individual's uncertainties, kindheartedness, similar to and dissimilar as regards to the surroundings which are corresponded through a quality (Yeung, 2005). When customers have a greater concern regarding the atmosphere, than greater number of consumers is agreed to pay for environment friendly products having little products that have a less injurious impact on the atmosphere (Peattie, 1995).

Men are less fearful concerning ecological problem than are women (Mostafa, 2007). Stern, Dietz, and Kalof, (2005), Women as compared to men, focus on those standards of the products that are going green. Bang, Alexander, John, and Traichal, (2000) disclosed in their learning that customers who have greater concern about the atmosphere are willing to pay more for environmentally friendly products as compared to those consumers who have less concern regarding the atmosphere. Dunlap (1994) declared that residents of Asia have a negative perception about their environment of their locality as compared to that of the other countries such as Europe. Moser \&Uzzell (2003), for instance, contend that audience's perception of the seriousness of the pollution the media's interpretation of pollution levels have an effect on problems.

Chen (2009) has prepared a theoretical sketch which represents the Green Brand Image, Green Satisfaction and Green Trust can enhance the green brand equity. Brand image is the judgment in the attitude of the consumer associated with the contribution. Product quality of firm desires to be enhanced with the intention to get a positive position among the competitors. Olsen (2002) stated that the extent of overall satisfaction experienced by a consumer is the fulfillment which is derived from the implementation of customer's necessities, requirements, and expectation by the brand. With distinctive feature of goods can discriminate the company's goods from their pretender (Parasuraman, Zeithaml, and Berry, 1988).Benefits for foodservice establishments of going green include the encouragement of a brand image in optimistic way that provides uniqueness over other restaurants in their segment, (Graci \& Dodds, 2008).

Adapted from (Mourad \& Ahmed, Perception of the green brand in an emerging innovative market, 2012) Model suppose that there is direct link between green brand preference as dependent variable and green practices as independent variable with additional sub independent as green brand image, green brand awareness, and environmental concern.

Green Brand Preference shows that how much people will prefer green products over conventional product. It is a dependent variable which tells how much it is depending on independent variable and its dimensions. 


\section{RESEARCH MODEL}

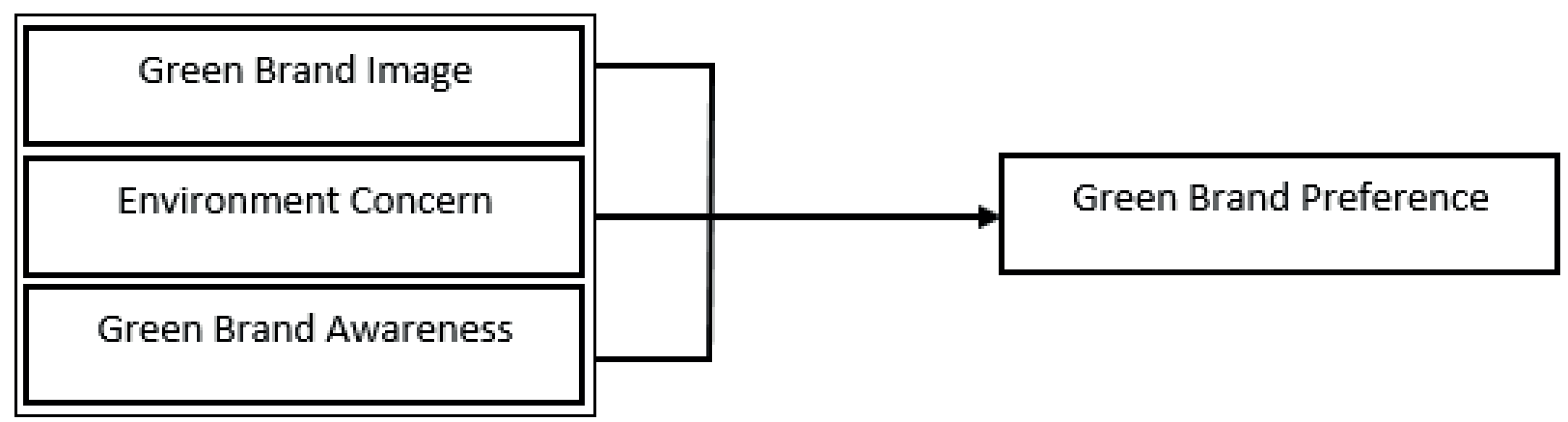

\section{HYPOTHESIS FORMULATION}

H1: There is a significant relationship between Green Awareness and Consumer's Brand Preference. $\mathrm{H} 2$ : There is a significant relationship between environmental concern and Consumer's Brand Preference.

H3: There is a significant relationship between green brand image and Consumer's Brand Preference. Methodology:

Data is gathered by using 5 point scale through strongly disagree to strongly agree it include 15 items about respondents graphics It contains questions about demographics, green brand image, environment concern, green brand awareness, and green brand preferences. The data was collected from different Universities (G.C University, University of Punjab, University of Engineering and Technology) in Lahore Pakistan.

\section{SAMPLING TECHNIQUE}

The population of this study is 350 students from different Universities (G.C University, University of Punjab, University of Engineering and Technology) in Lahore Pakistan. In this study, cluster sampling is used in which the population is divided into different groups known as clusters after this population is selected randomly from these clusters. In this sampling technique population is mutually homogeneous while internally heterogeneous. 


\subsection{EMPIRICAL FINDING}

Table 1 Missing Value Analysis

\begin{tabular}{|l|c|c|c|}
\hline Variables & N & Count & Percentage \\
\hline Green Brand Awareness & 350 & 0 & .0 \\
\hline Green Brand Awareness a & 349 & 1 & .3 \\
\hline Green Brand Awareness b & 350 & 0 & .0 \\
\hline Green Brand Awareness c & 347 & 3 & .3 \\
\hline Green Brand Awareness d & 345 & 5 & 1.4 \\
\hline Green Brand Awareness e & 349 & 1 & .3 \\
\hline Environmental Concern & 344 & 6 & 1.7 \\
\hline Environmental Concern a & 350 & 0 & 0 \\
\hline Environmental Concern b & 349 & 1 & .3 \\
\hline Environmental Concern c & 345 & 5 & 1.4 \\
\hline Environmental Concern d & 348 & 2 & .6 \\
\hline Environmental Concern e & 348 & 2 & .6 \\
\hline Green Brand Image & 347 & 3 & .3 \\
\hline Green Brand Image a & 345 & 1 & 1.4 \\
\hline Green Brand Image b & 350 & 0 & 0 \\
\hline Green Brand Image c & 347 & 3 & .3 \\
\hline Green Brand Image d & 348 & 2 & .6 \\
\hline Green Brand Image e & 348 & 2 & .6 \\
\hline Green Brand Preference & 347 & 3 & .3 \\
\hline Green Brand Preference a & 348 & 2 & .6 \\
\hline Green Brand Preference b & 347 & 3 & .3 \\
\hline Green Brand Preference c & 348 & 2 & .6 \\
\hline Green Brand Preference d & 347 & 3 & .3 \\
\hline Green Brand Preference e & 347 & 2 & 1.4 \\
\hline Age & 344 & 3 & 1.7 \\
\hline Marital status & & 6 & \\
\hline Economic class & & & \\
\hline
\end{tabular}




\subsection{FREQUENCY TABLE}

Frequency of the data is used to explain the quantity of the data. It explains the demographic data more precisely that how much data contain on male and female when under discussion demographic characteristics is gender.

Demographic profile of respondents:

385 items are divided to star 350 questionnaires completed by the respondent which shows $92 \%$ efficiency. This able consist of respondent information. Universities (G.C University, University of Punjab, University of Engineering and Technology) in Lahore Pakistan

Table 2.

\begin{tabular}{|l|c|c|}
\hline Respondents Demographics & Frequency & Percentage \% \\
\hline Gender(N=347) & 42.0 & 58 \\
Male & 147 & 42 \\
Female & 88 & 25.1 \\
\hline occupation(N=350) & 262 & 74.9 \\
Employed & 101 & 28.9 \\
Unemployed & 225 & 64.2 \\
\hline Age(N=346) & 08 & 2.2 \\
Below20 & 02 & 0.6 \\
21-25 & 07 & 2.0 \\
26-30 & 08 & 2.3 \\
31-35 & & \\
36-40 & 42 & 12 \\
Above40 & 298 & 85 \\
\hline Marital status $(\mathrm{N}=345)$ & 03 & 0.8 \\
Married & 07 & 2.0 \\
Single & & \\
Divorced & 83 & 23.7 \\
Widow & 109 & 31.7 \\
\hline Economic class(N=340) & 104 & 29.7 \\
Upper & 28 & 8.0 \\
Upper middle & 26 & 7.4 \\
Middle & & \\
Lower middle & & \\
Lower & & \\
\hline
\end{tabular}

The table shows that out of 347 respondents 147 (42\%) are males and 420 (58\%) are female; three respondents did not provide any information regarding their gender. Of the 350 respondents 101 (28.9) are below the age of 20 years, 225 (64.2\%) are within 21-25 years, 08 (2.2) are within 26-30 years, 02(0.6) are in the age group of 31-35, 07 (20) are in the age of 36-40 and 08 (2.3) are aged above 40.346 give their information on the basis of their occupation: $88(25.1 \%)$ are employed, 262 (74.9). Of the 350 respondents,345, provided information on their marital status: 42(12\%) are married, $298(85 \%)$ are single.03 (0.8) are divorced and $07(2.0 \%)$ are widow. Out of 350 respondents 341provided information on the basis of their economic class: 83(23.7) are from upper class, $109(31.7 \%)$ are from lower middle class, 104(29.7) are from middle class, 28(8.0\%) from lower middle class $26(7.4)$ belongs from lower class. 
Table 3. Respondent profile

\begin{tabular}{|c|c|c|c|c|c|}
\hline Items & $\mathbf{N}$ & Min & Max & Mean & Std.Dv \\
\hline I have heard of environment friendly products. & 347 & 1.00 & 4 & 2.47 & 1.03 \\
\hline $\begin{array}{l}\text { If you notice the environmental label on brand } \\
\text { you'll prefer to use it }\end{array}$ & 345 & 1.00 & 4 & 2.92 & 0.97 \\
\hline $\begin{array}{l}\text { Environmental advertisements play their role } \\
\text { to make me aware of green brands. }\end{array}$ & 350 & 1.00 & 5 & 1.7 & 1.02 \\
\hline $\begin{array}{l}\text { Newspaper and magazine are also a source of } \\
\text { awareness regarding green brands. }\end{array}$ & 348 & 1.00 & 5 & 2.1 & 0.82 \\
\hline $\begin{array}{l}\text { I get awareness about green brands from friends } \\
\text { and relatives. }\end{array}$ & 347 & 1.00 & 5 & 2.04 & 0.96 \\
\hline $\begin{array}{l}\text { I'm more concerned about protection of } \\
\text { environment. }\end{array}$ & 342 & 1.00 & 5 & 2.10 & 0.97 \\
\hline $\begin{array}{l}\text { I would describe myself as environmentally } \\
\text { responsible. }\end{array}$ & 342 & 1.00 & 5 & 2.200 & 0.96 \\
\hline $\begin{array}{l}\text { Environmental degradation has risen in last } \\
\text { decade }\end{array}$ & 339 & 1.00 & 5 & 2.18 & 0.94 \\
\hline $\begin{array}{l}\text { Environmental protection will help people } \\
\text { have better quality of life. }\end{array}$ & 347 & 1.00 & 5 & 2.03 & 0.90 \\
\hline $\begin{array}{l}\text { Organizations promoting green products are } \\
\text { concerned about the environment. }\end{array}$ & 349 & 1.00 & 5 & 2.06 & 0.94 \\
\hline $\begin{array}{l}\text { Branded products satisfy my expectations } \\
\text { about environment safety. }\end{array}$ & 345 & 1.00 & 5 & 2.05 & 0.93 \\
\hline $\begin{array}{l}\text { Packaging of Well-known branded products is } \\
\text { recyclable. }\end{array}$ & 346 & 1.00 & 5 & 2.06 & 0.92 \\
\hline $\begin{array}{l}\text { The brand's environmental repute is handled } \\
\text { appropriate manner. }\end{array}$ & 348 & 1.00 & 5 & 2.29 & 1.04 \\
\hline $\begin{array}{l}\text { Quality of organic products is better than } \\
\text { conventional products. }\end{array}$ & 348 & 1.00 & 5 & 2.12 & 0.91 \\
\hline $\begin{array}{l}\text { The brand is successful in its environmental } \\
\text { performance. }\end{array}$ & 347 & 1.00 & 5 & 2.25 & 1.10 \\
\hline $\begin{array}{l}\text { I prefer to buy those brands which are } \\
\text { environment friendly. }\end{array}$ & 338 & 1.00 & 5 & 2.200 & 0.96 \\
\hline $\begin{array}{l}\text { I prefer to buy products of those companies } \\
\text { who have "Green certification" }\end{array}$ & 339 & 1.00 & 5 & 2.18 & 0.94 \\
\hline $\begin{array}{l}\text { I prefer to consume green products because } \\
\text { they increase my prestige. }\end{array}$ & 339 & 1.00 & 5 & 2.04 & 0.90 \\
\hline $\begin{array}{l}\text { I prefer green products over conventional } \\
\text { products. }\end{array}$ & 346 & 1.00 & 5 & 2.10 & 0.92 \\
\hline $\begin{array}{l}\text { I prefer green products because they are easy } \\
\text { to dispose of. }\end{array}$ & 342 & 1.00 & 5 & 2.06 & 1.00 \\
\hline
\end{tabular}




\section{RESULTS AND ANALYSIS}

\subsection{PRINCIPLE COMPONENT ANALYSIS}

For the improvement of the factor on every item is rotated at their required level Green brand image, Environment concern Green brand awareness, and Green brand preference. PCA used in this study to develop better outcome for every tested variable to produce main item. To check the data is useful for factor analysis KMO and Bartlett's test is done.Eigen value more than one in factor loading items of factors should homogeneous within group but heterogeneous with each other.

Table 4. Reliability

\begin{tabular}{|c|c|c|c|}
\hline Variables & No of question & Number of Items & Cronbach's Alpha \\
\hline Green brand image & 350 & 6 & 0.823 \\
\hline Environment concern & 350 & 5 & 0.866 \\
\hline Green brand awareness & 250 & 6 & 0.830 \\
\hline Green brand preference & 250 & 3 & 0.870 \\
\hline
\end{tabular}

This study includes level Green brand image, Environment concern Green brand awareness, Green brand preference As in Cronbach's alpha values of buying behavior, packaging knowledge, color, material, wrapper design, and innovative packaging are $0.823,0.866,0.830,0.870,0.766$ and 0.727 respectively.

Table 5. Principal Component Analysis

\begin{tabular}{|c|c|c|c|c|}
\hline Constructs & $\begin{array}{c}\text { No. of } \\
\text { Items }\end{array}$ & KMO & $\begin{array}{c}\text { Sphericity } \\
\text { Chi-square }\end{array}$ & $\begin{array}{c}\text { Sphericity } \\
\text { Sig. }\end{array}$ \\
\hline Green brand image & 3 & 0.738 & 544.866 & .000 \\
\hline Environment concern & 3 & 0.699 & 409.271 & .000 \\
\hline Green brand awareness & 3 & 0.739 & 683.361 & .000 \\
\hline Green brand preference & 3 & 0.728 & 511.750 & .000 \\
\hline
\end{tabular}

Here we apply factor analysis using PCA to check the validity of data. KMO measure the sample of the data. Values of KMO are $0.738,0.699,0.739,0.728$, and 0.752 are respectively. KMO standard value is 0.50 so in this study KMO value is greater than 0.50 which show the validity of the data. In Bartlett's chi-square we check the significant level. In this paper significant value of all items is 0.000 which allow running successfully

Table 6.

\begin{tabular}{|c|c|c|c|c|}
\hline Constructs & Components & $\begin{array}{c}\text { Initial Eigen } \\
\text { Values }\end{array}$ & & \\
\hline & & Total & \% Variance & Cumulative \% \\
\hline Green brand image & 1 & 2.543 & 84.780 & 84.780 \\
\hline Environment concern & 1 & 2.366 & 78.859 & 78.859 \\
\hline Green brand awareness & 1 & 2.510 & 83.678 & 83.678 \\
\hline Green brand preference & 1 & 2.408 & 80.250 & 80.250 \\
\hline
\end{tabular}


The following table shows the components of different construct have Eigenvalue of greater than 1. For Packaging knowledge, material, color, design, innovative only 1 component is principal component.

Table 7. Factor Loadings

\begin{tabular}{|l|c|}
\hline ITEMS & COMPONENT \\
\hline Green Brand Awareness & PK \\
\hline I have heard of environment friendly products. & $\mathbf{. 9 0 7}$ \\
\hline If you notice the environmental label on brand you'll prefer to use it & $\mathbf{. 9 3 2}$ \\
\hline $\begin{array}{l}\text { Environmental advertisements play their role to make me aware of green } \\
\text { brands. }\end{array}$ & $\mathbf{. 9 2 3}$ \\
\hline $\begin{array}{l}\text { Newspaper and magazine are also a source of awareness regarding green } \\
\text { brands. }\end{array}$ & \\
\hline I get awareness about green brands from friends and relatives. \\
\hline Environmental Concern & $\mathbf{. 9 2 8}$ \\
\hline I'm more concerned about the protection of environment. & .929 \\
\hline I would describe myself as environmentally responsible. & .887 \\
\hline Environmental degradation has risen in last decade & \\
\hline Environmental protection will help people have a better quality of life. & \\
\hline $\begin{array}{l}\text { Organizations promoting green products are concerned about the } \\
\text { environment. }\end{array}$ & $\mathbf{\text { PM }}$ \\
\hline Green Brand Image & .901 \\
\hline Branded products satisfy my expectations about environment safety. & .903 \\
\hline Packaging of Well-known branded products is recyclable. & .860 \\
\hline The brand's environmental repute is handled appropriate manner. & \\
\hline Quality of organic products is better than conventional products. & .853 \\
\hline The brand is successful in its environmental performance. & .901 \\
\hline Green Brand Preference & .837 \\
\hline I prefer to buy those brands which are environment friendly. & \\
\hline I prefer to buy products of those companies who have "Green certification" & \\
\hline I prefer to consume green products because they increase my prestige. & \\
\hline I prefer green products over conventional products. & \\
\hline I prefer green products because they are easy to dispose of. & \\
\hline
\end{tabular}

This table shows that shows just one item as standard for every item Green brand image, Environment concern Green brand awareness, Green brand preference 
Table 8. Correlation Analysis:

\begin{tabular}{|c|c|c|c|c|}
\hline Variables & $\begin{array}{r}\text { Green brand } \\
\underline{\text { image }}\end{array}$ & $\begin{array}{r}\text { Environment } \\
\text { concern } \\
\end{array}$ & $\begin{array}{r}\text { Green brand } \\
\underline{\text { awareness }}\end{array}$ & $\frac{\text { Green brand }}{\text { preference }}$ \\
\hline $\begin{array}{l}\text { Green brand image } \\
\text { Sig. ( } 2 \text { tailed) } \\
\mathrm{N}\end{array}$ & 350 & $\begin{array}{l}.039 \\
.464 \\
350 \\
\end{array}$ & $\begin{array}{r}.461^{\star *} \\
.000 \\
350 \\
\end{array}$ & $\begin{array}{r}.719^{* *} \\
.000 \\
350 \\
\end{array}$ \\
\hline $\begin{array}{l}\text { Environment concern } \\
\text { Sig. ( } 2 \text { tailed) } \\
\mathrm{N}\end{array}$ & $\begin{array}{l}.039 \\
.464 \\
350\end{array}$ & 350 & $\begin{array}{r}.131^{\star} \\
.014 \\
350\end{array}$ & $\begin{array}{l}.050 \\
.353 \\
350\end{array}$ \\
\hline $\begin{array}{l}\text { Green brand awareness } \\
\text { Sig. ( 2tailed) } \\
\mathrm{N}\end{array}$ & $\begin{array}{r}.461^{\star *} \\
.000 \\
350\end{array}$ & $\begin{array}{r}.131^{\star} \\
.014 \\
350\end{array}$ & 350 & $\begin{array}{r}.549^{* *} \\
.000 \\
350\end{array}$ \\
\hline $\begin{array}{l}\text { Green brand preference } \\
\text { Sig. ( } 2 \text { tailed) } \\
\text { N }\end{array}$ & $\begin{array}{r}.719^{\star *} \\
.000 \\
350\end{array}$ & $\begin{array}{l}.719 \\
.000 \\
350\end{array}$ & $\begin{array}{r}.549^{\star *} \\
.000 \\
350\end{array}$ & 350 \\
\hline
\end{tabular}

Correlation shows the strength of the relationship between variables. It can be perfect positive +1 to perfect negative -1 .

Table 9.

\begin{tabular}{|c|c|}
\hline Coefficient range & Strength \\
\hline $.00-.19$ & Very week \\
\hline $.20-.39$ & Weak \\
\hline $.40-.59$ & Moderate \\
\hline $.60-.79$ & Strong \\
\hline $.80-1.0$ & Very strong \\
\hline
\end{tabular}

As shown in the table

There is an insufficient weak linear relationship of there is significant linear relationship Green brand image, Environment concern Green brand awareness, Green brand preference.

There is a very strong correlation Environment concern Green brand awareness.

H1: There is a significant relationship between Green Awareness and Consumer's Brand Preference.

H2: There is a significant relationship between environmental concern and Consumer's Brand Preference.

H3: There is a significant relationship between green brand image and Consumer's Brand Preference.

Table 10. Regression Analysis

\begin{tabular}{|c|c|c|c|c|}
\hline Regression & $\frac{\text { Un standardized }}{\text { Co-efficient }}$ & $\begin{array}{c}\text { Coefficient } \\
\text { Error Standard }\end{array}$ & $\underline{\text { T value }}$ & Sig \\
\hline Constant & $-7.064 \mathrm{E}-18$ & .028 & .000 & .000 \\
\hline Green brand image & .306 & .49 & 6.263 & .000 \\
\hline Environment concern & .90 & .028 & 3.230 & .001 \\
\hline Green brand awareness & .001 & .034 & .027 & .978 \\
\hline Green brand preference & .274 & .047 & 5.806 & .000 \\
\hline
\end{tabular}


The following table shows that there is significant and positive relationship. Green brand image, Environment concern Green brand awareness, Green brand preference.

Table 11. Necessary Statistics

\begin{tabular}{|c|c|c|c|}
\hline $\mathbf{R}^{\mathbf{2}}$ & Adj. $\mathbf{R}^{\mathbf{2}}$ & F-statistics & Prob.(F-statistics) \\
\hline .859 & .739 & 194.429 & .000 \\
\hline
\end{tabular}

Adjusted R2 $=.739$ in this case which means that impact of product packaging on student buying behavior is explained variance $73 \%$. F-test $(\mathrm{F}$ statistics $=194.429 \mathrm{p}$-value $=0.00)$ means that all independent variable effect on dependent variable is significant and our model is a good fit.

H1: There is a significant relationship between Green Awareness and Consumer's Brand Preference. $\mathrm{H} 2$ : There is significant relationship between environmental concern and Consumer's Brand Preference.

H3: There is a relationship between green brand image and Consumer's Brand Preference.

\section{CONCLUSION AND RECOMMENDATIONS}

This study shows significant results with respect to green brand preference and its critical characteristics of student brand awareness. This study concluded that the importance of green brand elements (green brand image, environment concern, on green brand awareness, H1 H2 H4.H4 are accepted.

H1: There is a significant relationship between Green Awareness and Consumer's Brand Preference. $\mathrm{H} 2$ : There is a significant relationship between environmental concern and Consumer's Brand Preference.

H3: There is a significant relationship between green brand image and Consumer's Brand Preference.

\section{THEORETICAL LIMITATIONS}

This study has a limitation on selected little sample size with dead timeline. The student is in negligence mode while completing questionnaire. This study performed in only Universities (G.C University, University of Punjab, University of Engineering and Technology) in Lahore Pakistan

\section{PRACTICAL IMPLICATION}

This study is applicable for the manufacturers and managers they must take in view green brand awareness when introducing products in the market.If they take poor in strategy and products may destroy in market. It is very necessary for managers to involve all green brand awareness to create student awareness and policies to attract student

\section{FUTURE RECOMMENDATIONS}

This study is used on constraint timeline in the city Universities (G.C University, University of Punjab, University of Engineering and Technology) in Lahore Pakistan due to small resources of money. In next-generation population sample size can be wide for accurate output to develop green brand awareness to capture student awareness about green brand. 


\section{REFERENCES}

[1] Chen, Y.-S. (2008), The driver of green innovation and green image - green core competence, Journal of Business Ethics, (81).

[2]Chen, Y.-S. (2010), The drivers of green brand equity green brand image, green satisfaction, and green trust, Journal of Business Ethics, (93).

[3]Dunlap, R.E. (1994), (International attitudes towards environment and development), in Bergesen, H.O.

[4] Parmann, G. (Eds), Green Globe Yearbook of International Co-operation on Environment and Development 1994, Oxford University Press, Oxford.

[5] Parasuraman, A., Zeithaml, V.A. and Berry, L.L. (1988), (SERVQUAL: a multiple-item scale for measuringconsumer perceptions of service quality), Journal of Retailing.

[6] Peattie, K. (1995), Environmental Marketing Management, Pitman Publishing, London.

[7] Nik Abdul Rashid, N.R. (2009), (Awareness of eco-labelin Malaysia's green marketing initiative), International Journal of Business and Management.

[8]Newing, R. (2011), (Environment: long-term impact ofgreen issues played down), Financial Times, 18 May.

[9] Parmann, G. (Eds), Green Globe Yearbook of International Co-operation on Environment and Development 1994, Oxford University Press, Oxford.

[10] Bang, H., Alexander, E., John, H. and Traichal, P.A. (2000), (Consumer concern, knowledge, belief, and attitude toward renewable energy: an application of the reasonedaction theory) Psychology and Marketing, (17)

[11] Crispell, D. (2001). Going Green. Public Perspective, September/October 2001.

[12] Vermeir, Iris, and Wim Verbeke (2004), (Sustainable Food Consumption: Exploring the Consumer "AttitudeBehavioral Intention" Gap), Journal of Agricultural and Environmental Ethics, 19 (October).

[13] Olsen, S.O. (2002), (Comparative evaluation and therelationship between quality, satisfaction, and repurchase loyalty), Journal of the Academy of Marketing Science, (30).

[14] Dunlap, R.E. (1994), (International attitudes towardsenvironment and development), in Bergesen, H.O. and Parmann, G.

[15] Graci, S. and Dodds, R. (2008), (Why go green? Thebusiness case for environmental commitment in the Canadian hotel industry), Anatolia, (19) .

[16] Moser, G. and Uzzell, D. (2003), Environmentalpsychology, in Weiner, I.,Millon, T. and Lerner, M. (Eds), Handbook of Psychology, Personality and Social Psychology, JohnWiley\& Sons, Inc., Hoboken, NJ.(Mourad \& Ahmed, Perception of green brand in an emerging innovative market, 2012)

[17] Newing, R. (2011), (Environment: long-term impact ofgreen issues played down), Financial Times, 18 May. 